\title{
From Produsers to Shareaholics: Changing Models of Reader Interaction in Women's Online Magazines
}

\author{
Laura García-Favaro \\ Department of Sociology, City University London, UK. \\ Laura.Garcia-Favaro.1@city.ac.uk
}

\begin{abstract}
Women's online magazines have been constantly proliferating and increasingly supplanting print publications. Contributing to their success, these sites offer similar content free of change and significantly greater opportunities for interaction - often in the form of discussion forums. However, these interactive spaces are currently disappearing, being replaced by an ever-escalating emphasis upon social network sites (SNSs). This article critically examines this changing model of reader interaction in women's online magazines, drawing on a study of 68 interviews with industry insiders, forum user-generated content, and a variety of trade material. The analysis demonstrates how the decision to close the forums and embrace SNSs responds to multiple determinants, including a corporate doctrine of control over users' discourse and outsourcing new modalities of free consumer labour, constituting a new ideal worker-commodity online: "the shareaholic". This exercise of power has varying levels of success, and potentialities remain for users to exercise some transformative subversion, for example through what the article theorises as "labour of disruption". Nonetheless, the emergent SNS-based magazine model of reader interaction poses a serious challenge to ongoing celebrations both in the industry and in some scholarly work about an increasingly democratic and user-led digital media ecosystem.
\end{abstract}

Keywords: Internet forums, online communities, social network sites, online journalism, women's magazines, feminism, The Vagenda, spreadable media

Acknowledgements: I am very grateful to Elisa Favaro Carbajal, Christian Fuchs, Rosalind Gill, Pip Sadler, Romina Surugiu, Laura Thompson, and City's CCl PhD seminar group for their helpful comments. Special thanks to all the journalists who agreed to take part in the research.

\section{Introduction}

The women's online magazine: astro, beauty, sex, diet, tests, quizzes, fashion, trends... Expert advice, interactive tools and sofeminine's fabulous forums!

-SoFeminine.co.uk

Seeking to capitalize on the increasing female Internet population, commercial woman-centred websites thrived from the late 1990s. These niche-oriented products offered content resembling women's magazines, shopping possibilities, and a new star feature: message boards or discussion forums, stressing notions of a female community. This proved to be a highly successful model. A decade later, commentators both in the media (e.g. Pfanner 2010) and in academic work (e.g. Campbell 2011) were still heralding the forums as key to the success of women's online magazines/websites, which are constantly proliferating and increasingly supplanting print 
publications. Yet, a few years on, these interactive facilities are vanishing. One evident reason is changing engagements with technology. In the context of a rapidly developing media(e)scape, forums are increasingly perceived as "relics of web 1.0" (Davies Jones 2015). Certainly, women's online magazines are replacing the forum system with an emphasis upon reader interaction via social network sites (SNSs), the icons of the "new web" (Tapscott and Williams 2006).

The present article aims to critically interrogate this changing model of reader interaction in consumer women's online magazines. To this end, it employs a multisourced and mixed-method research design, examining almost seventy interviews with industry insiders, user-generated content from the forums, together with a variety of trade material. The study demonstrates how the decision to close the forums and embrace SNSs responds to multiple determinants, including outsourcing new modalities of free consumer labour, and a corporate doctrine of control over users' discourse. More generally, the article captures the changing and evolving form of the woman's online magazine market, which has received little attention by media and communication scholars. In doing so, I aim to make a contribution to the sociological analysis of developments in the digital media era - its technologies, cultures and political economies, highlighting the importance of incorporating a feminist perspective.

Commercial online magazines targeting women constitute a particularly useful case study of changing approaches toward audiences by corporate digital media. More broadly, as Duffy $(2013,4)$ argues: "Women's magazines provide a compelling site to examine [...] questions about how 'traditional' media industries are transforming in a digital era of media". Not only are these publications acutely commerciallydictated as they are almost entirely supported by advertising (McCracken 1993), but they are also a distinctively resilient media, and one which has embraced convergence more than any other "traditional" medium, developing into multi-platform, omnipresent "magabrands" (Duffy 2013). In addition, women's magazines epitomise the narratives and strategies - as well as contradiction and ambivalence-that have come to characterise the commercial digital media landscape at large. That is, they hinge on claims to a unique media-audience proximity, even "shared identity" (McRobbie 1996), the mobilisation of notions about "community" and "empowerment" (Winship 1987), along with the co-optation of elements from social emancipatory movements (particularly feminism) (Mcdonald 1995). These problematic dynamics are succinctly evoked by this columnists' description of the global brand Cosmopolitan:

For me, it represents a place where feminism is fabulous. It's a supportive community of women who care about social issues AND shoes. If Cosmo were a person, it would be your best friend, squeezing your hand and whispering 'you go, lady!' (Devon 2015)

In what follows, I first discuss key theorisations of interactivity in digital media contexts, offering a brief historical overview, and paying particular attention to the critical frameworks informing this study. Next, I introduce women's online magazines, charting both the rise of digital-only titles and the development of web extensions by wellestablished print publications. The remainder of the article is an empirically-supported discussion about shifting approaches to reader interactivity in women's online magazines. 


\section{Theorising User Interactivity}

As the Internet popularised during the 1990s, narratives about the radical emancipatory and democratic potentials of cyberspace began to circulate widely. For example, Levy (1997) developed the notion of "collective intelligence"; Pearce (1997, xvii) talked about an "interactive revolution", declaring that: "Binary code is the digital Esperanto that is leading concurrently to individual empowerment and worldwide unity"; and Plant $(1996,170)$ (re)interpreted the development of decentralised information networks as signalling a feminisation process, with claims that "virtual worlds": "undermine both the world-view and the material reality of two thousand years of patriarchal control". From the late 1990s onward, many of these optimistic stances came to be widely contested. For instance, in light of the widespread celebration of the Internet as a woman's medium, Balka pondered in 1999: "I wonder where all the feminist information technology critics have gone, and I fear the answer is that we've been seduced by the potential of the World Wide Web". Scholars highlighted how early discussions were dominated by a focus upon non-commercial sites and ad hoc social aggregations such as fan communities (e.g. Baym 1995), and hence called for research that broadened the scope of investigation to "the more mainstream, everyday practices of internet use", a task which was perceived to be "especially relevant as the internet and the World Wide Web become more ubiquitous and more commercialised" (Consalvo and Paasonen 2002, 4). In this regard, studies highlighted how ecommerce was facilitating user communities to increase site "stickiness" and to cultivate loyalty (Jarrett 2003).

With the rise of the web 2.0, narratives of community building, participation and empowerment have only intensified. These pervade the media industry, as well as academic work. One notable example is Jenkins $(2006,9)$, for whom media convergence has brought about a "participatory culture" constituted by "active" and "socially connected" "newly empowered" consumers. This culture, Jenkins $(2006,4)$ argues, leads to "collective intelligence", understood as "an alternative source of media power". In a similar vein, Bruns $(2007,100)$ maintains that "social software or Web 2.0 environments" indicate a paradigm shift toward a "new user-led information-age", foreseeing a democratic model based on the activities of "produsers" (a produceruser hybrid) (see also Tapscott and Williams 2006). Critical Internet scholars have (again) problematized this position. For Fuchs $(2009,96)$, it demonstrates a "new techno-deterministic optimism", resembling the "ideology that accompanied the commercial rise of the Internet in the 1990s", and constituting a "web 2.0 ideology". With reference to Convergence Culture (Jenkins 2006) specifically, Driscoll and Gregg $(2011,567)$ declare that: "ideological analysis [...] is sorely needed when cultural, media and especially Internet studies appear ready to serve as the prophets for new industries". Noting Jenkins' emphasis on fandom, Driscoll and Gregg (2011, 567) also caution Internet researchers against (once more) "allowing the practices of a minority to stand as the optimistic vision of the imminent media landscape". Also complicating the work of Jenkins, Andrejevic (2011a, 613) emphasises that marketers employ narratives about "community" and "engagement" as "strategies for managing interactive audiences", where: "The goal is not so much collective bargaining with interest groups as it is covert and pre-emptive opinion tracking on an unprecedented scale". In turn, Deuze $(2008,31)$ highlights that: "much of this participatory culture is heavily regulated, constrained or embedded within company processes and practices that strive to 'harness' rather than 'unleash' participation"; and notes how: "the corporate appropriation of social media [...] opens up new opportunities for companies to enlist the 'free labor' (Terranova 2000) of media users". Indeed, with the 
rise of social media the "digital labour" debate has become central to critical media and communication studies (Fuchs 2014; see also Scholz 2013).

Analyses of productivity in digital networks through the theoretical lens of "free" "immaterial" labour (e.g. Hardt and Negri 2004) posit corporate industry as investing in digital technologies to redefine the relationship between the spheres of production and consumption. User interactivity and participation are considered to be exploited in various ways as forms of labour that generate marketable commodities and other types of (commercially-exploitable) value. For instance, focusing on affinity portals Campbell (2011) has drawn on Jhally and Livant's (1986) "work of watching" model to argue that users perform a type of work on behalf of corporations paralleling that which commercial television audiences perform in exchange for television content, namely exposing themselves to advertisements in exchange for access to the cultural and social resources being offered. Further, in her early important intervention Terranova $(2000,42)$ highlighted how the "productive capacities of immaterial labour on the Internet", like "the work of writing/reading/managing and participating in mailing lists/Web sites/chatlines", significantly enhance-or even constitute-the value of online spaces. In such a manner, the "audience commodity" (Smythe 1977) becomes a "produser commodity" (Fuchs 2009). Moreover, in response to offers of convenience, personalisation and participation, consumers of commercial digital media submit to comprehensive surveillance and, in doing so, produce exploitable data for mass customization and targeted marketing (Andrejevic 2003). Subsequently, for Andrejevic $(2003,197)$, in engaging with digital media consumers "are not so much participating, in the progressive sense of collective self-determination, as they are working by submitting to interactive monitoring". This "work of being watched" facilitates turning the "details of activity that once eluded systematic forms of value extraction" into "information commodities" (Andrejevic 2011b, 90).

As Andrejevic (2003) also points out, exploring how interactivity doubles as forms of labour does not entail a dismissal of the possibilities of deriving enjoyment, engaging in creative activity or building meaningful relationships, nor does it deny that audience practices have potential for empowerment. The point of this critical scholarship is rather to challenge "media ideology 2.0", based upon an "automatic association between interactive participation and democratic empowerment" (Andrejevic $2009,36)$. The point is to highlight the ways in which "new media technologies are being deployed in many contexts according to priorities that reproduce the very forms of alienation they promise to overcome" (Andrejevic 2011c, 2), for example concerning power and control over information. Critical Internet research likewise aims to draw attention to "the important line between access to the means of online content production and ownership or control over these resources" (Andrejevic 2011b, 97) a line which became forcefully evident when forumers on women's sites faced the permanent closure of the(ir) forums. In exploring this "moment" in the history of the woman's online magazine market, the present article responds to calls for critical Internet researchers to address issues of gender and gendered media (e.g. Ouellette and Wilson 2011; Duffy 2013; Jarrett 2014).

\section{The Commercial Woman's E-Space}

With the take-over of perceptions of cyberspace as a place for commerce and audience commodification in late 1990s, "communication" and "community" emerged as key e-commerce strategies, and women as "the new and promising consumers" (Sadowska 2002, 90). Although the female user remained as the marked gendered category online, this now became "commodified as a desirable demographic for con- 
sumption" (Consalvo 2002, 133), a yet unexploited goldmine for marketers that was particularly appealing in light of increasing numbers of women going online and their independent spending power achieved in recent decades (Sadowska 2002). By stressing communicative and community-building aspects, the market began to fervently position the Internet as offering women novel opportunities to express their femininity (Gustafson 2002; Royal 2005; Worthington 2005). Most typically, however, the dot.com industries promoted segregated commercial e-spaces for women, then sometimes called "she sites" (e.g. CNET 2002) or "pink sites" (e.g. Price 1998).

The quintessential model emerging out of this process was the "affinity portal" or "community site". This model was developed by new players coming to the entrepreneurial arena of the Internet hoping to compete with established universal portals such as Yahoo, AOL or MSN, and to obtain a share of emerging online audiences (Campbell 2008). The latter notably concerned socially marginalized and oppressed groups, particularly due to gender (e.g. iVillage.com), sexuality (e.g. Gay.com) and ethnicity (e.g. BlackPlanet.com), with corporations using "inviting images of community to suggest they are more than merely a commercial site" (Campbell 2008, 8). Crystallising this strategy of address was the discussion forum or message board offering, which in the case of women's portals encouraged user communication about a variety of traditionally feminine topics like beauty, fashion and relationships, thereby mirroring the site content. Indeed, these sites were firmly rooted in the woman's magazine publishing tradition (Paasonen 2002; Sadowska 2002). This meant incorporating its essentialist notions about gender, and addressing readers "as a single unified community by virtue of its femaleness" (Litosseliti 2006, 93) - "the world of women" (Ferguson 1983, 6). A case in point are the slogans of two US-based pioneers: "The Internet for Women" (iVillage.com) and "A Woman's View of The World" (Oxygen.com). "Woman', here, stands for feminine as communicative, sharing, and caring", Consalvo and Paasonen noted $(2002,7)$.

The new "popular women's sites" or "magazine-like Internet portals" (Sadowska 2002, 94) soon because the object of feminist scrutiny and debate, as part of a broader critical interrogation of the evermore powerful online political economy that was enthusiastically emphasizing the feminine-even also feminist-qualities of the net (van Zoonen 2001; Seiter 2003). Feminist scholars condemned how these sites primarily positioned women as consumers, and were "using essentially feminine stereotypes to promote and position their content" (Royal 2005, vi), very much like the oft-critiqued printed women's magazines (e.g. Ballaster et al. 1991). Moreover, it was highlighted how the sites incorporated discourses from the women's movement about community - "but without any political edge" (Paasonen 2002, 95). Responding to these criticisms, Eble and Breault $(2002,316)$ maintained that the editorial content was of secondary importance for users, linking instead the success of women's sites to the interactive features. Even if not "overtly feminist or alternative", for Eble and Breault $(2002,326,317)$ the forums were a valuable space "where women could produce, consume and exchange information, knowledge or advice about various topics". During this period, there were proliferating feminist studies showing that far from offering the dramatic alternatives to patriarchal oppression envisioned by some early cyberfeminists (e.g. Plant 1996), the Internet involved for women the same genderbased divisions, discriminations and power relations (e.g. Kramarae and Taylor 1993; Brail 1996). As such, Eble and Breault $(2002,318)$ also emphasised that contrasting most online spaces these forums allowed women to communicate in a safe environment, with little or no competition with-or flaming and harassment from-men. Gustafson $(2002,185)$ similarly noted that "the ability of these communities to bring 
groups together cannot be entirely discounted". However, she also problematized how "with the promise of community" and "by using rhetoric of empowerment and self-direction" these "commercially controlled structures" were seeking to "attract women and encourage them to form predefined affinity groups, neatly packaged for marketers" (Gustafson 2002, 185-186).

Outside academic circles, early critiques of these sites were marked by a sense of disillusionment, in light of the expectations set by some early ventures such as Women.com (previously Women's Wire) and Oxygen.com, which "promised to provide alternatives to the shallow women's glossies on newsstands" with diverse, intellectual and politicized content (Brown 2000). For example, a ClO Magazine piece entitled "Women's Websites Insult My Intelligence" stated: "Although they promised us a revolution, these sites are a devolution, hosting content that harks back to the worst June Cleaver-ish prefeminist tripe" (Genusa 2001). A Salon article equally wondered: "What happened to the women's Web? They promised a revolution, but all we got was horoscopes, diet tips and parenting advice" (Brown 2000). Pointing to the intimate connection between these new sites and the established woman's magazine genre, together with the increasing company mergers and acquisitions of Internet properties by media giants, this article also declared:

Other than a certain emphasis on resourcefulness, do-it-yourself-ism and profemale positivity, there isn't much difference between the front page of iVillage and the cover of Family Circle, that of Women.com and Cosmopolitan (whoops, Cosmopolitan is now part of Women.com) (Brown 2000).

The rising popularity of the Internet among women and the ready availability of similar free and updated content online threatened the-already fiercely competitivewoman's magazine print market. In a survival effort, from the 2000 s onward publishers began to embrace the web. At first this entailed posting online content created for the print version, as a "tester" to entice readers to purchase the magazine. This was an ineffective approach, forcing publications to develop online-specific content and strategies. These were especially based around immediacy and interactivity, and often included the incorporation of "community" spaces, notably forums. In the 2010 s, as Duffy $(2011,50)$ observes, "interactive websites that once served as mere "companions' to the print-bound magazine have now become the gold standard for magazine publishers". While print circulation is largely declining, in line with the publishing industry generally and consumer magazines in particular, an online model is catapulting the reach of brands - compare for instance Cosmopolitan UK's combined print and digital monthly circulation of 405,308 to the 6.5 million unique users its website engages (Cosmopolitan 2016).

Nowadays, the web extensions of print publications and online-only titles are effectively indistinguishable. This is due to their mutual influence, ongoing media mergers and acquisitions, along with the recent increasing self-designation of the online-only sites as magazines. One example is the changing self-description by FemaleFirst.co.uk from a "destination site" and an "online community" to the current Twitter handle: "women's lifestyle magazine". Further blurring these boundaries, some print editions have folded and shifted to an online-only model (e.g. Grazia Spain). Also, as part of their internationalisation strategy well-established brands are expanding to new markets with online-only local publications, such as Cosmopolitan Nigeria, launched in 2015. Large publishing houses are likewise developing digital-first brands. One example is Bauer Media's The Debrief, a British online lifestyle maga- 
zine launched in 2014 for the "constantly connected ABC1 20 something female" (The Debrief 2014). Here the word "community" is nowhere to be seen. The new discursive landscape has instead been taken over by an enthusiasm about "native advertising", "real-time data", "shareable content", and "social platforms", but not forums. The established sites are following this very same path. For example, in 2014 Elle Spain said "good-bye to the forums" as follows":

After more than six years, we say good-bye to the forums [...] Thank you to all of you who during these years participated with your conversations and remember that we will stay in contact via our profiles on Facebook, Twitter, Instagram, Pinterest, Youtube, Vine and Google Plus.

In the last few years, social media analytics have become a crucial element of the media packs publications prepare to sell advertising opportunities. For example, British Elle (2016) boasts of 1.1 million Twitter followers and 5 million Facebook "likes", promising potential commercial partners to be: "Inspiring customer connection and interaction". It is to interrogating the shifting nature of such interaction that I now turn.

\section{Women's Online Magazines Explored}

This article is part of a larger research project on consumer magazines for young ${ }^{2}$ women, examining representations of gender, sex and sexuality, along with the ways these publications relate to feminism, and respond to the digital era. The research focuses on twelve popular online magazines that are hosted in the two different European contexts of the UK and Spain: the online-only FemaleFirst (independent), SoFeminine (AuFeminin-Axel Springer) and The Debrief (Bauer) in the UK, EnFemenino (AuFeminin-Axel Springer) Grazia (Mondadori) and Nosotras (ITnet Group) in Spain; together with the well-established global brands Cosmopolitan (Hearst UK/Gruner+Jahr Spain), Elle (both Hearst) and Glamour (both Condé Nast) in both countries. Despite their country of origin, these sites are predominantly owned by multinational companies, and are accessed by users worldwide. In addition to offering cultural-contrastive insights, the research maps transnational patterns, as highlighted in the present paper.

The larger research project integrates qualitative analyses of four types of data: a) editorial magazine content; b) user discussions in the forums; c) a wide assortment of texts connected to publications, including promotional material like media packs/kits, news and trade press, and published interviews with editors; and d) my own producer interviews. Between December 2014 and February 2015, I conducted 68 interviews with magazine professionals, primarily editors and writers, who were working or had worked as staff or freelance for at least one of the selected publications. Research participants were mainly female (62), and, apart from some "top" editors, coincided with the target audience in age (early-20s to mid-30s). Almost all had first degrees, many also postgraduate qualifications, and were mainly based in the capital cities of London and Madrid. With the exception of two email-based communications, interviews were semi-structured, averaged over one hour in duration and took place via

\footnotetext{
${ }^{1}$ All translations from Spanish in this article are mine. From: http://www.elle.es/revistaelle/mundo-elle/cierre-foros-elle Accessed 19/02/2016.

${ }^{2}$ Following the practice in the woman's magazine industry, "young" is here used to refer to the 18-35 age bracket, which at present constitutes the generation of people often referred to as Millennials (born between 1980-2000).
} 
Skype (32), in cafés (27), on the phone (4), at the participants' office (2) and home (1).

In what follows, I primarily focus on the user-generated content and on the interviews with producers. First, I take the Cosmopolitan.co.uk forum as a case study to explore the ways users utilised the platform and reacted to the closure announcement. Turning to the interview data, the next three sections examine how producers explain the increasing closures or abandonment (e.g. by reducing the prominence of the section and deleting links) of the discussion forums in women's online magazines. I begin by looking at critiques of the forum system itself, then move on to discussions about SNSs, and end by examining (continued) moments of tension between producers and users in these new platforms. By way of concluding, I offer some theoretical and political notes on the new paradigm identified in the empirical analysis.

\section{1. "Chat Away to Your Heart's Content": The Cosmopolitan Forums}

Jump into our buzzing Cosmopolitan forums to discover a world of scandal, hilarity and sisterly support. Chat away to your hearts content.

-Cosmopolitan.co.uk, early 2010's

The Cosmopolitan.co.uk forums will be closing and moving to 'readonly' at the end of November. We apologise for any inconvenience this may cause. It's not you, it's us. $x$

-Cosmopolitan.co.uk, 2014

Between the years 2006-2014, Cosmopolitan.co.uk offered a platform for audience interaction in the form of a discussion forum. This was divided into a number of inbuilt topic-specific sections, which were mostly in line with the central foci of the publication, such as beauty, fashion and sex, but also included others like "news and debates" and "careers and cash". The discussions were publicly accessible, although registration was required to post messages ${ }^{3}$. People-primarily self-identified women-utilised the platform to anonymously discuss a varied range of issues under the section headings, even engaging in meta-debates, for instance: "are there some topics which are too sensitive, taboo or horrible to be debated?" and "Cosmopolitan A 'Safe Space' for Feminist Talk?"4 More frequently, the forums were used to disclose personal problems and ask for advice and support, with thread titles like "Please help! i need advice!" and "Confused and worried" saturating this online space. Some registered on the Cosmopolitan forum to discuss a single, specific issue. One example is the thread "Sexual assault and new partners", where the thread-starter explained: "I made this account for this purpose, because I did not want to risk to be identified, but the struggle I am facing is real". A more typical use of the forums is well-represented by the following self-introduction to the community: "I came on here to talk to people about our girl problems, to also have some help myself and to basically just make some friends".

\footnotetext{
${ }^{3}$ For a critique of rules governing usage in these sites, see Gustafson (2002).

${ }^{4}$ These were publicly accessible forums that allowed anonymous commentary through pseudonymisation. Here all names/pseudonyms have been removed for further deidentification. The presented extracts are direct quotations, and so all capitalisation and errors remain as in the original post.
} 
A fundament "girl problem" in the "Cosmo universe" concerns appropriately performing the feminine labour of aesthetics and consumption. Threads like the following were pervasive: "Eyebrow tint- wedding emergency!", "Blusher colour help!", "What top do I wear with this skirt?" By requesting and providing advice on the pains and pleasures, successes and failures with services and products women were therefore doing free market research work for companies. Equally speaking to debates about free consumer labour in digital contexts, one key activity in the forums was what Campbell $(2011,492)$ calls the "labour of devotion", namely "where consumers participate in the promotion of corporate brands through interactive media". For Campbell (2011), this mode of consumer work is both distinctive of corporate-engineered online communities and clearly gendered, grounded in the market assumption that women, as supposedly innate social beings, actively promote their favourite brands to other women. Indeed, this was a motivating factor for the forum offering in women's websites. For example, a year after the launch of EnFemenino.com (AuFeminin) in 2001, the then editor celebrated: "It is proven that women speak three times more than men about their experience with a brand" (Cubillo in Baquia 2001). A decade later, the AuFeminin CEO was still promoting this gendered consumer, putting to work the performative power of discourse: "A great difference is that, while men are difficult to influence (apart from by their wives) yet women are influenced by a number of women" (Sauty de Chalon 2011). In Cosmopolitan.co.uk, the forumers' labour of (brand) devotion was particularly pervasive in the "Hair \& Beauty" and "Fashion and Shopping" sections, conveniently matching the industries which provide most of the advertising revenue to the magazine. Two illustrations are: "I find Chanel skin care products a great treat, the make up amazing and the perfumes gorgeous" and "I really LOVE the Maxfactor Masterpiece mascara". As well as its actual and potential commercial partners, this digital labour also benefited Cosmopolitan directly: "i never head to the high street until l've checked out the latest issue of Cosmo - keep up the good work!"

It was not all consumer devotion, however. In the forums, women also expressed dislikes and disappointments with brands: "Topshop is terrible quality it is no better than primark", "Riverisland is bad for washing", etc. Again, Cosmopolitan itself was also critiqued. One example is: "Cosmopolitan is a money making franchise that exploits women for sales. Rather read something that will expand your mind, instead of poorly written drivel on celebs and bad sex tips". There were even threads dedicated to debating the quality of the publication, such as "does cosmos dumb you down?" and "is cosmos sexist?" In these discussions, some would distance the forum (usergenerated content) from the magazine (editorial content): "The forums are different as they really have nothing to do with the magazine" and "The forum is great; it is real people, talking about real issues. But I view the articles on the website the way I view the Sun; trashy". Supporting claims in feminist research on audiences of women's magazines (e.g. Frazer 1987; Hermes 1995), self-defined readers also offered critical readings of editorial textual practices. This includes challenging the feminist credentials of publications due to their emphasis on hyper-sexualised women, their limited standards of beauty, along with their profound (ideological) contradictions:

Although I appreciate what Cosmopolitan is trying to do in terms of making their online space a more feminist space, I just don't see any progress being made. I mean, the models being shown throughout the website are, for the most part, still being portrayed in a very hyper-sexualized manner, as sex icons. The women are representing the 'ideal beauty' of the culture: slim, 
white, heterosexual, with perfect blonde hair, glazing blue eyes and with perfect smooth skin.

I love this forum, but some of the [editorial] advice articles are not good. I read one that implied if your $\mathrm{OH}$ [other half] had changed or improved a sexual technique it meant he was cheating. This was along side a "sex help guide" on how to please your man/how to please your woman!

Unlike the magazine, by and large the Cosmopolitan forum evaded criticism. On the contrary, forumers repeatedly depicted the platform as an important space of advice and support. For example: "l'd probably have topped myself a long time ago had it not been for cosmos. I know it's only a forum but people don't realise how much it helps others. It's fabulous. X" Repeatedly praised was the possibility to communicate anonymously: "It's great to be able to ask frank, honest questions without the worry about what people think - love it!" Another example is:

I love the fact that people on here always give good advice and support. It's great to know that if you don't want to share it with real world people, you can come online and share your thoughts and problems with people on here and they're willing to help.

The Cosmopolitan forum was filled with messages revealing intimate details and stories of hardship. This was particularly notable in the most popular section, "relationships", described by Cosmopolitan as follows: "From your man to your mum or your best friend, discuss your latest relationship dreams and dilemmas". Here threads featured a diversity of sensitive issues/topics like: "My Boyfriend hit me with a beer bottle", "pregnant and feeling so alone...", "My ex boyfriend has passed away", and "Is my marriage doomed". The "sex" section-"Drop your inhibitions and talk about all subjects sexual. From emotional issues to hot techniques"-similarly included discussions ranging from things such as "My boyfriend wants us to use a strap on" to the very delicate "have u been raped i have? :-(". This supports previous observations that in anonymous online spaces people tend to feel comfortable disclosing information and talking about matters considered too intimate or sensitive, inappropriate or even dangerous for face-to-face and other forms of public conversation, making Internet forums especially attractive to socially vulnerable populations (Herring et al. 2002).

This attachment became vividly evident when Cosmopolitan announced the permanent closure of the forum (see the second quote opening this section). The community reacted by expressing gratitude to fellow members, for example: "thank you for sharing your thoughts, hopes, fears, dreams, problems etc online", "Thanks to everyone who ever listened to me, read my nonsense or engaged with me", and "Thank you for the years of memories ladies". Furthermore, both active forumers and "lurkers" posted messages stressing the significance of the platform for them and others:

It's a shame. A lot of people came on here looking for advice they couldn't get anywhere else including myself. 
I was often more of a lurker than an active member, but it was nice to know that if I needed it, there were people on here willing to give advice and support.

Fuck sake Cosmo threads have really helped me for some really hard times from debating leaving my first (abusive, animal porn addicted) ex through to general concerns about my job...Really going to miss you all.

Goodbye : xxxxxxxxxx

That is, there were vivid expressions of sadness and loss by users when Cosmopolitan announced it was closing the forum. Two additional examples are: "Guys I'm going to miss so many of you and find it really sad l'll never speak to some of you again" and "*sigh*. This has made me sad, l've spent a lot (probably too much!) of time on here over the years, and made some really good friends. Will miss this place". There were also a few posts voicing gratitude to the brand for having offered the platform. Noteworthily, the post below indicates diversity in contributors (something mostly missing in the editorial team) as "one of its great strengths":

I've read some hilarious and fascinating things, been offered emotional support when I needed it and been able to offer it in return. I've had some fun debates and some nasty debates but all have been entertaining. I've interacted with a wide range of individuals that I would never have met or conversed with if it weren't for Cosmo/ Hearst. [The forum] was literally a cosmopolitan melting pot of people and that was one of its great strengths.

In contrast, a larger number of forumers expressed anger at the decision, and raised various critiques against the Hearst brand, not least because: "All the money that cosmo must be making, surely the cost of running this forum is a pittance to them!" Other illustrations of this reaction are:

It has been a pleasure.

Cosmopolitan you are fucking arseholes and I will never be buying your piece of shit misogynists dream magazine again. You suck Cosmo.

Cosmopolitan sells lies to vulnerable people. Our forum was a lifeline. And now it is being closed. No explanation, nothing. Hearst is a company run by incompetent, lying, useless fucktards.

There is something perverse about the way companies invoke notions of community to extract free labour and construct ever more narrow and emotionally involved consumer niches, and generate revenue "by selling audiences as markets to advertisers often under the guise of 'serving' their respective minority community" (Campbell $2008,22)$. This does not mean, however, that people are users-turned-workers operating under some form of "false consciousness", deceived or "duped" by marketers (Campbell 2011). As seen, the Cosmopolitan forumers articulated critiques of the editorial content, along with an understanding of the profit imperative and revenuegenerating strategies of this media. This includes an awareness of the significant value users added to the site as commercial enterprise, for example in terms of driving traffic and providing ideas for the editorial: "Apparently driving traffic to the website, 
giving them stuff for the magazine and being a supportive community is not enough when you're wanting cash - eh Hearst?"

In light of the impending closure, the members of the forum community discussed "migrating" to a different online space. A Facebook private group was created for this purpose, leaving many behind due to a perceived lack of anonymity in this new platform:

I prefer keeping anonymous so if anyone does have another forum that they know members are going too, let me know. Adios Cosmo, you've been great (:)

[Response] Will miss you sparkles There's a group on fb, but that's obviously not anonymous. It has been a pleasure.

Oh im so disappointed $:)$ l'd prefer to remain anonymous so unfortunately this is probably goodbye to most of you!

Overall, the users lamented the closure of the Cosmopolitan.co.uk forum as an important loss, particularly because of the general consensus that "these boards were a great source of advice and opinion", together with support and belonging. In addition to disappointment, many contributors (understandably) expressed surprise. All previous communications by Cosmopolitan had endorsed the forum community (see the opening quote of this section). For example, on announcing the 2011 site relaunch the acting web editor posted in the forums: "we want to make sure that you - the Cosmo community who are the heart and soul of the site - have the best possible experience on the website". Media coverage similarly highlighted that this re-design included: "A complete makeover of the ever-popular community forums" (InPublishing 2011). As late as January 2014, the webmaster was announcing the winners of the annual "Cosmo Community Awards", which comprised ten categories, including "allaround nicest member" and "best debater". So what led Cosmopolitan to discard the forums only a few months later in their November 2014 relaunch? Cosmopolitan never offered an explanation beyond "it's not you, it's us x", in what was a remarkably silent (or silenced?) operation, which remained ignored by all the attention the new site otherwise received (e.g. InPublishing 2014). The producers of women's online magazines gave a varied range of reasons for the mounting rejection of the forum model of reader interaction. These are examined in the next three sections, which are based on the analysis of nearly 70 interviews with industry professionals.

\subsection{Repudiating Forums: Spammers, Trolls... And Users Out of Control}

In response to growing feminist critiques of the corporate community sites for women that were booming in the early 2000s, Eble and Breault $(2002,317)$ argued for an understanding of these spaces as valuable "women's marketplaces-online, primetime agoras" (see also Section 3). In our interview a product manager working for a Spanish site with highly popular forums made the very same comparison: "before people conversed in the village squares, in Ancient Greece. This is like an agora, you have different stalls and people assemble according to interests". Further accentuating this sense of public gathering and open debate, he added: "We have always understood that the forums aren't ours, they are the users'. So it's a place where we need to let them communicate among themselves". As well as benefiting their corporate image of being user-centred and of serving the needs and interests of women, this level of (relative) discursive freedom in the forum is important for magazines be- 
cause: "it gives us trends, patterns, really valuable information you wouldn't be able to obtain otherwise".

One important way publications utilise this "really valuable information" from forums is to shape the editorial content. This was repeatedly confirmed when I asked about sourcing information and ideas for pieces. "I'd read the forums and read what people were talking about, and what readers wanted to know and get general gist", a writer responded. A features editor similarly explained that: "When we had our features meetings, l'll always go on there, because they're under the categories of our magazine. See what people are talking about". In the forums, magazine producers noted: "people are much more willing to talk more openly about issues such as sex". This can provide useful insights and inspiration for features. For some, however, this openness also means that conversations often go "a step too far" to be useful for the elaboration of editorial content. That is, the explicit, detailed and/or non-normative character of much forum user-generated content about sex can block the extraction of value from the forumers' "work of being watched" (Andrejevic 2002). For example

The sex and relationship section of my work website... we get a lot of what I would consider quite inappropriate conversations that I couldn't then translate into an article because it would just take it a step too far. (Staff writer, late-20s, UK)

In a similar manner, a number of journalists claimed to generally dislike the nature of commentary in forums for being "very immediate, anonymous, impulsive". These online spaces were additionally described as too often "weird", and certainly "controversial". "And obviously, we've got a duty to make sure there isn't anything too controversial on the chatroom because we're responsible for that", remarked an editor from the UK. Articulated at times was a discourse of concern for the wellbeing of the reader. For example: "You'd see some people giving some really horrific advice, medically unsafe advice and emotionally unsafe advice". Others problematized what was perceived as a shift in the type of engagement found in these spaces: "Historically forums were the big platform for chat, debate, everything else. Now a forum is somewhere to be a dickhead". Indeed, women's magazine producers claimed that these online spaces are repeatedly employed to be "bitchy", "nasty" and "aggressive". Some even related the increasing rejection of a forum model of user interaction to growing wider concerns about cyber-bullying. For a British freelance writer: "a lot more websites are very careful about how much they let people interact with each other because what's happened in recent times with online bullying and that kind of thing". Internet forums were similarly described as a "playground for trolls", as well as "fortune-tellers", "weight loss things" and spam. Moreover, some journalists shared experiences of encounters with scams, and even other illegal activities like child laundering on a few occasions.

Subsequently, at the centre of explanations about the increasing closures or disinterest in forums was "the issue of moderation and control". A former digital director from Spain told me that: "A forum is free, there isn't any previous moderation. You post a message and it's instantly up. Obviously, that's a bottomless pit. It's impossible to control". Equally, for a Spanish online editor: "Forums are a hotchpotch you

\footnotetext{
${ }^{5}$ The information provided after the presented interview extracts was agreed upon with each research participant. I have omitted elements when I have felt that the anonymity of the individual might potentially be compromised. Note that staff reshuffling and new appointments might have taken place since the interviews were conducted.
} 
have no control over". "You just can't police something's that so massive, that was why that decision was taken", explained a British features editor. The desire to be in control was not all due to trolls, spammers, and scammers, however. For some producers, this user-led space is an unwelcome competitor for user attention, and (hence) a waste of editorial efforts. "It's sad for people to come to your magazine because of a [forum] comment about anti-contraceptives, it's like 'and all my work for nothing"', expressed a Spanish fashion and lifestyle online editor. Again contrasting the discourse of consumer care discussed above, the producers of women's online magazines repeatedly highlighted forums as detrimental for the "image and reputation" of the brand. Of particular concern was "negative publicity" deriving from "association" with the sex topics discussed by forumers. In Spain especially, there was an additional significant concern about the sex-related language. For example, a former Spanish digital editor stated that, in contrast to the writers: "the users speak in an explicit way and that sounds very vulgar for the magazine". Both in Spain and in the UK, this perceived inappropriateness of the user-generated content about sex was a contributory factor for the decision to close the platform. In explaining the closure of the popular forum run by her magazine, an editor said:

At one point, if you put "rimming" into Google, [magazine] came up second top search because on the forums people were talking about rimming so much it came up second when you put it in. And that's not really our--obviously, we are a sex and relationship bible but we're not particularly going to be that. (Editor, UK)

Still, the producers of women's magazines contended that: "the censorship is more from a commercial rather than an editorial point of view" (note the use of the strong term "censorship"). Fundamentally, explicit or less conventional sex-related discussions deter advertisers. "There have been issues in the past where particular things on the website [forum] have had to be taken down before they would advertise with us", elucidated a British staff writer. In other words, the user-generated content intensifies what is already a complicated terrain for these publications, namely negotiating changing cultural sensibilities and practices concerning sex/uality with the boundaries of taste and respectability demanded by luxury or otherwise glossy (mainly beauty) brands.

Further diminishing the appeal of the platform for women's online magazines is the fact that advertisers do not consider forums an appropriate space to promote products/services. This is due to an "attitude" a Spanish product manager described as one of: "I control everything that is said about me in all platforms and spaces". As others also put it, "clients don't want to be in the forums" because "everybody has the power to comment". After I asked why her magazine had closed the forum, a director equally explained that:

A forum isn't economically profitable because there are no brands involved. Well, in our case. I imagine that there are several media that actually do make a profit, but big luxury brands don't want to be in a forum. Why? Because the content is so free that anything can come out. (Digital director, mid-30s, Spain)

One vital thing that can "come out" is consumer dissatisfaction with products/services. Indeed, as seen in the previous section, the users of women's online 
magazines are not always as docile and devoted to brands as companies expected or hoped. This causes conflict between publications and their advertisers:

We've had advertisers who advertised in the web and would then receive lots of criticism in the forums because their product wasn't good, according to the users. And the advertisers would then tell us to eliminate those comments. (Audiovisual producer, mid-20s, Spain)

In this sense, a community manager from Spain emphasised that: "There are a lot of problems with aesthetic clinics". By closing the forums magazines "make advertisers and PRs happy" as they (re)gain control of the reviews potential customers encounter in these sites, which are key for the cultural re/production of the "beauty myth" (Wolf 1991) and "consumer femininity" (Talbot 1995).

A number of magazine producers explained the closures of forums by making distinctions between forumers on the one hand, and on the other the "consumers that advertisers want to reach". Others differentiated forumers from readers, asserting that "the people who are on the chatrooms weren't particularly reading any of the articles", but were rather using the web "only as a facility" to communicate among themselves. This was associated to the criticisms the publication was receiving from the forum community, which was another factor contributing to the closures. A writer explained:

We noticed that the forum community wasn't the same community as would buy the magazine, or it would even consume the content on the website. And that was where a lot of the aggression was, "you're going to lose all of your readers because we don't want to read your crap". So, it was only as a facility. (Digital writer, mid-20s, UK)

Preferred to forums were the comment sections below editorial articles. Comment sections, which are increasingly connected to SNSs (primarily Facebook), assist magazines in their attempt to maintain reader commentary in line with the editorial content. Note below how "we wanted our readers" is corrected to "it's about what they want":

The conversations that were happening [in the forum] were not necessarily in line with the kind of things that we wanted our readers--not wanted our readers to be talking about, it's about what they want. But we wanted the conversations to be in line with our content really. So the way to do that is to lead the conversations underneath each piece of content. (Features editor, late-30s, UK)

In addition to topical divergence from the editorial content, there was a general condemnation of the tendency for forum conversations to "go off into oblivion" and "tangents". Here, again, the more restrictive comment sections were favoured. In the words of a British editor: "We'd rather people commented underneath the articles to guide their chat a bit more because people were going off on these different tangents". Again indicating an effort by corporations to order a perceived disorder online (Jarrett 2005), this editor also observed that closing the forum of the website: "It just makes it more neat as well".

On the whole, when discussing the forum facility the producers of women's online magazines stressed that: "it's just more hassle than it's worth". Forums, I was told, 
are resource-demanding, "really, really time-consuming to monitor" and, ultimately, "impossible to control". This involves scammers, spammers and trolls - but also "unruly" users, namely: women disregarding the topical borders established by the publication and sharing "unglossy" personal stories-mainly concerning sex-as well as expressing critical views about and problems with brands. The findings therefore support a Spanish freelancer who critically argued that: "when one doesn't open a forum, it's because one doesn't want there to be dialogue". In his view: "there are fantastic Internet tools to filter the disturbing interference of some [e.g. trolls] without impacting upon the freedom of the community, who could enjoy that opening". However, according to this freelancer, women's magazines want to avoid hearing "criticism of brands and editorial lines". "And as a result come the closures and the restrictions", he added. The way magazines are attempting to gain control over user expression while maintaining narratives of "customer connection and interaction" (see Section 3 ) is by shifting to a model based on SNSs.

\subsection{Endorsing SNSs: Newness, Profit.... And (Re)Gaining Control}

Forums have converted into Facebook comments and Twitter publications. The forums are finished. (Digital writer, mid-20s, Spain)

When I asked about the decreasing corporate interest in forums, I was repeatedly told that visiting these spaces: "It's kind of an older thing"; and, more specifically, that: "they're very nineties". What is more, for many the Internet forum is "an obsolete system". ${ }^{.}$In terms of searching for answers to problems, journalists pointed to the greater availability of information, and user desire for immediacy. For example: "Online there is so much information that you don't need to go to a forum to ask a question and wait [...] we now ask our questions directly on the search engine". Concerning engaging in discussion, it was maintained that: "People don't use them [forums] anymore because everyone has gone over to talking about things on Facebook". Indeed, magazine producers declared that: "The forum is now Facebook and Twitter". This includes those who still had forums in their websites. "I don't think they have much of a future on our site", expressed a staff writer, also remarking that: "There's buttons of 'follow us on Twitter', 'follow us on Facebook'. We removed the forum button".

In other words, technological developments and attendant changing patterns of use come into play to systematically push women's online magazines to close down discussion forums and move onto platforms like Twitter and Facebook. After all, glossies are built upon the eternal quest for the new and upcoming, not to mention the most profitable - and SNS referral has surfaced in recent years as the main traffic driver. "In terms of traffic, social media is huge. It's huge"7 , all magazine industry insiders emphasised. Vividly capturing recent shifts, the newly forum-free Cosmopolitan.co.uk 2014 redesign was announced to have been "developed to prioritise mobile and social media", because: "Currently $54 \%$ of readers primarily access Cosmopolitan.co.uk via mobile devices" (InPublishing 2014). Cosmopolitan UK also revealed that: "Our mobile traffic is our social traffic" (Odell in Welton 2015); and that: "73\% of

\footnotetext{
${ }^{6}$ Some would observe that forums still work for "specialist things" like fitness, and, most repeatedly, parenting sites like the UK-hosted Mumsnet. "It's something that mums look for, it's not something for a general women's lifestyle website", said a British staff writer, suggesting how consumer segments are constituted and put to work in different ways by corporations.

${ }^{7}$ Research participants use the phrase "social media" to refer to SNSs specifically.
} 
our traffic [is] coming from social media" ${ }^{8}$. SNSs have become key spaces for (viral) brand image transmission and content broadcasting: "Twitter is the new newsstand", stated a Spanish writer. Magazine professionals celebrated that: "If it's all on Facebook, it's minimal effort required to do it, it's going much further, it's resulting in more ad revenue". The move to SNSs was thus also welcomed in terms of "efforts-reward ratio" with regard to time, resources and cost. A platform like Facebook, in contrast to forums: "It's free and you don't have to monitor it". Notwithstanding their importance, these factors do not necessarily explain the abandonment of the forum system altogether. Sites like EnFemenino.com combine both models. Also, these logics alone do not-again, necessarily-account for the closure of forums that were popular, such as those hosted by Cosmopolitan UK. My data point to a varied range of different factors coming together in the push away from forums and toward SNSs. Building on the previous section, in what follows I wish to highlight one important such factor: corporate efforts to exercise control over user-generated content.

As already discussed with respect to comment sections, an advantage of closing forums and using SNSs industry insiders mentioned in the interviews is the manner in which the latter help companies better restrict and shape discussions. Magazine professionals highlighted that SNSs encourage the delimitation of user participation to commenting on individual editorial features, and thus the topics (carefully) curated by publications as opposed to those brought up by the users themselves. An editor-inchief appeared to anticipate critique of this corporate move with the observation "we still discuss as many things":

Laura: Why did the forum close down?

Editor-in-chief: It just worked for us better to have people talking on the social media pages rather than a separate forum that didn't necessarily engage with the content that was up. So it sometimes become like a separate conversation, whereas it makes sense that everyone is having the same conversation about lots of different things, we still discuss as many things.

That is, rather than interrogate the reason why their content failed to engage users with a view to opening a dialogue and modifying editorial lines, publications decide to obliterate this channel of communication altogether - even when its value for users was evident. When discussing the recently closed forum of her website, a writer noted that: "what we realised from it was that clearly people have questions that they want answering". She then continued: "But in terms of directing our focus it needed to be on content rather than facilitating people that weren't interested in our content".

Another way SNSs help magazines exercise greater control over users' discourse pertains to the imposing presence of the brand, which the industry translates into benign-sounding narratives of "being part of the conversation". This corporate intention is explicitly articulated in the following endorsement of SNSs (and repudiation of the forum system):

For all of our readers to be talking to each other is nice but we want to be a part of that conversation. Because I feel like a forum is very much the readers' chats themselves. Yeah... you wanna be in control. (Staff writer, mid-20s, UK)

\footnotetext{
${ }^{8}$ From: "The 5 key things you'll benefit from by advertising on Cosmopolitan.co.uk", http://www.cosmopolitan.co.uk/about/a31085/advertise/ Accessed 26/02/2016
} 
Producers are thus aware of the silencing impact of the brand presence. It was besides acknowledged that forum discussions and comments on Facebook and Twitter are "not the same concept" and "not the same type of dialogue", as the former consists of exclusively peer-to-peer communications. Again demonstrating the conscious censoring of users by these companies, a Spanish community manager also affirmed that: "you can't talk about everything on social media". Magazine journalists highlighted that contrasting the uninhibited character of forum discussions SNSs involve a general increase in control of self and other due to a decrease in anonymity. Endorsements of this user-silencing process include:

Social media is probably the best forum place. It's safer because there's limits on what you--limits what you can post. (Former sub-editor and community manager, late-20s, UK)

The majority of us aren't as personal on Facebook as people were in forums. It's kind of anonymous in forums. On Facebook, everyone knows you. If you write something ridiculous, people are going to be like, "what are you talking about? You're crazy". (Staff writer, mid-20s, UK)

In addition to shaping the nature of communications, SNSs help magazines exert greater control-and make more profit-by shaping the manner in which users communicate with each other. These online publications are transferring the emphasis away from users producing their own content and toward users sharing branded/professional content. In terms of editorial work, this involves an increased focus upon viral content: "SEO [search engine optimization] is really important for online. So, so important in terms of ranking and stuff like that, but right now we really have to focus on viral content, too. [...] The most important thing about viral content is it's shareable". The objective of the new digital strategy was expounded as follows:

Someone will take a viral piece that we have, "Twenty-Five Things We Wish Men Knew". We share that on Facebook, but people share that as a way of saying, "read it because I totally agree with it". This is a way of expressing their feelings instead of saying, "you know, I wish guys would do this", like writing their own personal comment. (Magazine professional, UK)

Forums bring together scattered anonymous discussants around topics. In contrast, SNSs emphasise social networks and personal profiles, both of which publications aim to penetrate and monetise via the sharing system. Concerning the former, the corporate reasoning is, in the words of a Wired.com article: "When media can spread through social networks, close personal connections are the distribution mechanism" (Honan 2014). With regard to profiles, magazine journalists explained that online: "you create this persona of your best self and we feed into that". As in typical in commercial media discourse, content sharing was often articulated via narratives of meeting consumer demand. Compare in the extract below "people want" to "you've got to shove it in their face" and "it's a massive contributor to our traffic":

People want to look funny or intelligent in that persona that they create on their social media, because it's a persona for everybody. So, if they come across something funny or intelligent, then they want to share it. So, to make that link as easy as possible, you've got to shove it in their face that, "actually this thing 
is really a cool thing that you found in the Internet". It's a massive, it's a massive contributor to our traffic. (Digital writer, mid-20s, UK)

Networked sociality was also celebrated as an ideal mechanism to boost "brand awareness" and "exposure". In the words of a British freelancer: "So that's the thing about sharing stuff, when something gets shared on Facebook, all of their friends are going to see it. So they may not read it, but they are going to be exposed to it". This new digital strategy means that for the site revamps: "One of the key things is making those share buttons much more prominent". Meanwhile, Cosmopolitan UK lays the discursive/ideological terrain with claims like: "In today's tech driven society, social status has never been more important and [...] all experiences [are] to be shared with our peers". Here Cosmopolitan is putting into practice the teachings by experts concerning the "new paradigm for online media", which emphasise that for the professional content provider: "the goal is to provide raw material for people to share [...] to build social capital" (Sarvary 2012). The "viral content scene", then, necessitates the digital reputation economy. As Hearn $(2010,423)$ explains, the latter "functions through forms of market discipline and affective conditioning, which, much like the practices of branding, work to direct human meaning-making and self-identity in highly motivated and profitable ways". Consumers' behaviour, relationships, and selves become "both the object and the medium of brand activity" (Moor 2003, 42 in Hearn $2010,426)$. Online this is an activity that is increasingly doubly branded, in light of the mounting use of "native advertising". As described by professionals themselves, this entails paying publications to "hide the advertising" in content produced by the editorial team. One British deputy editor told me that this is the model that works online because "people are too savvy and they get cross [...] if you put adverts everywhere" since "they see the Internet as their space". Namely, the branded content model helps corporations maintain the-commercially necessary-illusion of "the people's Internet".

However, women's online magazines extracted value from the unbranded usergenerated content of the forums: the anonymous users "on a tangent" writing "their own personal comment" via "threads that go on for years" were also often a source of ideas for editorial texts. When I pointed this out, a features editor from the UK responded: "I do think you have lost that something on the forum in that readers aren't coming up with new topics. We can only see how they're responding in terms of what we've written rather than coming up with everything". At the editorial level, the shift from a forum to a SNS-based model of reader interaction entails a shift in focus away from: "this is what they're talking about", and toward: "how many people have shared this? How many people have looked at this?", which could potentially further limit the range of voices and topics these publications feature.

Reader monitoring is becoming unprecedentedly central to women's magazine journalism (and beyond). Companies are constantly developing tools to monitor users in an even more sophisticated, extensive and intensive manner. As a Spanish product manager explained: "we have tools developed by the company to hear the social noise, what people talk about in the forums, what people talk about in other websites, where people are going, etc." In the larger publications like Cosmopolitan, monitoring technologies also include "a screen in the office with a list of what people are looking at right now which is on all the time". Companies are embedding this within the daily practice of journalists through motivational activities like competitions: "We have a lot of competitions to see who's going to write the most popular article, have arguments over it, that sort of thing. So, that is a really good motivation tool for 
us". Indeed, the talk of women's magazine producers is generally characterised by a sheer fascination with the analytics, responsiveness and immediacy of the Internet. One Spanish digital director told me: "I love the medium, for the speed, the data, the analytics, for the immediate audience feedback". Another enthusiastic description of online journalism is:

The thing with the web is that you can see it as soon as it comes on Twitter. You can see it as soon as they put a comment on the article. You can immediately respond. You can immediately kind of gravitate toward the things they want to see. Just monitoring how your features do. Monitoring shares, monitoring how it does in social. (Freelance writer, mid-20s, UK)

On some occasions, concern was expressed about this obsession with analytics. For some producers, it leads to the deterioration of the quality of the content produced. "The quality has lowered, ultimately the Tweet matters more than the content", declared an online editor from Spain. One British freelance writer similarly reflected: "Everything is based on the psychology of marketing. It's almost like the content doesn't actually matter anymore".

Most repeatedly, the increased surveillance of users was translated into celebratory notions about a "far closer relationship" or "greater engagement between writer and audience". Magazine producers applauded that with the Internet: "you're able to respond quicker to your audience and have that dialogue with them". Many specifically pointed to SNSs. I was told that "with the invention of Twitter and Facebook, there's more of a dialogue" and "there's definitely more of a channel". However, "dialogue" or "channels" to increase understandings of this notoriously opaque industry 9 are rare - and unlikely to rise any time soon. According to industry insiders, "a lot of editors don't often do interviews" because "they don't want the scrutiny", and "don't want to talk about the difficult points of women's magazines" or to have to deal with "uncomfortable questions". This importantly concerns the influence and power of advertisers. Reasons to evade discussions about this issue include investments in notions of "journalistic integrity", and, primarily, a fear of "upsetting advertisers". In this sense, I was told that: "It's not hard to upset an advertiser, and if you upset an advertiser, that is quite a serious thing". A related reason pertains to the necessity to maintain a "fiction" for readers described as follows:

There is a kind of fiction, I suppose, which a lot of readers don't realise it's fiction, as evidenced by the fact they complain about the advertising. They think the whole thing is being produced for them. If you start talking about the influence of the advertisers on it, you're basically saying, "you are not our priority" or "you might be our first priority, but you're followed up by a very very close second priority". And also because relationships with the advertisers are very... They do exert their influence. They do chuck their toys out and threaten to drop off and not advertise anymore. (Content director, late 30s, UK)

The very real negative consequences of upsetting an advertiser, in the context of a labour market that is not only highly competitive and precarious but also profoundly

\footnotetext{
${ }^{9}$ For example, scholars have pointed to significant challenges in recruiting participants for research (e.g. Gough-Yates 2003; Murphy 2013), which partly explains the scarcity of producer-oriented studies of women's magazines, particularly when compared to analyses of readers and especially texts.
} 
sexist and (thus) offering female journalists limited opportunities, is one of the reasons I have elsewhere advocated for a "solidary-critical" position when researching these media professionals (García-Favaro Forthcoming). This includes understanding critique as offering participants "tools to think with" in order to collectively push for cultural and structural transformation within the industry, as desired by many insiders, for whom holding critical views entails maintaining a "love-hate relationship" with the magazines they produce (and consume). This study accordingly corroborates the claim by Gough-Yates $(2003,24)$ that women's magazines: "are objects of discourse and sites of contestation not only for their readers, but for their producers as well". Contributing to the existing literature, my producer interviews also point to a similar "love-hate" dynamic with respect to readers, which, as I explore below, is rendered more complex and intense online.

\section{4. "We Hear You, Tweeters": Users Remain Unruly}

Once more complicating the narratives of greater dialogue, reader interaction often received criticism by women's magazine producers as soon as it transcended the mere sharing of editorial content. Many journalists complained that users "feel like they have a right to contact you". For a British freelance writer: "online readers do have an element of 'I can' because they feel like they have a closer relationship". This is arguably a reasonable consumer response to the longstanding and persistent promotion of women's magazines as a "best friend", alongside notions of a shared producer-consumer identity. In the same way, I was repeatedly told in the interviews that: "we're there to be their best friends", and that: "our team is basically the audience". These industry narratives have only intensified online. "I describe the site as our readers' smartest, funniest, most insightful friend", announces a Cosmopolitan.com editor (Odell in Welton 2015). In turn, Bauer boasts that: "The Debrief is written for these girls by these girls (no one older than 26 in the team!)" (The Debrief 2016). Still, users are expected to be media and marketing-aware enough to know how to "read" branding strategies and behave accordingly, reflecting the surfaced normativity of (particular articulations of) "media literacy" under contemporary neoliberalism. The following interestingly makes connections between the "types of people" who contact brands on friendly terms and those who "would take to a forum" and "feel this community":

We get a lot of comments on Facebook and things. I actually think, "God, I would never sit there and, unless I had a complaint, write on a brand's Facebook, like just commenting as if it was a friend". I just wouldn't do that, but a lot of people do. I suppose those are the similar types of people that would take to a forum, that feel this community and that it was taken away from them. (Digital writer, mid-20s, UK)

More frequently portrayed as a problem emerging from the increased "channel" online is having to face higher levels of critique. For a British freelancer: "Online people do feel like they have a right to critique you, attack you in some ways, or be a little bit more confrontational with you". A Spanish digital director similarly said that users are "more critical", "less devoted and love you less" than readers. She explained this in terms of the low rate of direct traffic to these sites. Others connected this consumer behaviour to SNS cultures in particular: 
People are more emboldened with Twitter and Facebook to say what they think, and they're not afraid to be critical or rude or very outspoken. Whereas before they would just think that and tell their friend but you as the producer would never hear that, now when someone dislikes something in [magazine] they'll take a picture of it and tweet about it and we'll see that. (Staff writer, mid-20, UK)

These observations were often located within a broader "pros and cons" accounting about online journalism. For example: "Online people aren't afraid to say they don't like something. People give us praise as well and that's always really nice". Online magazine journalists, then, lauded the possibility to get "a better sense of your reader" and receive praise, but struggled because: "you face much more criticism as an editor, as a writer". Also problematized was the greater exposure online, since as a producer: "You can hide behind your print edition a little bit more" ${ }^{10}$. Still, SNSs offer magaines tools to "hide" and reduce the impact of unwanted moments of "negativity" or "backlash". For example, it was highlighted that: "you can turn off messages on Facebook"; and that: "on Twitter, if you're not responding to anything, it's difficult for other people to see what people are tweeting at you". Brands also take advantage of the "more disposable" nature of SNS content, wherein they can more imperceptibly ignore critical commentary. "In Facebook it gets pushed down because you've got new stuff coming in", one professional explained. Moreover, under the SNS model of audience interaction even negative commentary is potentially beneficial for the magazine, as it can serve to "boost the profile of the web" and encourage "more people to get involved and click on it to see why people are arguing". Here, again, I was reminded of the following: "Efforts-reward ratio. It's that simple".

Despite all these attempts, women's magazines are not in full control of audience discourse online, nor can they fully ignore critique. In fact, web 2.0 technologies, cultures and uses are having a profound impact on these publications. Industry insiders asserted that women's magazines are "being more a lot more careful" and "checking themselves in fear of being scrutinised or told off" in light of "your younger audience", who is "so Internet literate" and "discerning". This means that: "The moment you stop putting content that doesn't feel legitimate to them any more they just won't visit you". Further notable challenges include "produsage" and a "call-out culture". A British digital health editor observed that: "social media has given people a platform to be able to say 'this content doesn't work for me [...] so I'm gonna create my own or I'm going to yell at you about yours". Magazines particularly fear a "PR disaster" deriving from a "Twitter war" or "social media trial", with many professionals pointing out that: "Mainly Twitter, but all social media, is very female focused and it's mostly female users". One editor further elucidated that:

As a publication, especially an online publication, you're aware that this is a possibility every time you put something out. Even if it's just in the back of your mind, you're going to want to try and appease that huge chunk of Twitter users

\footnotetext{
${ }^{10}$ Although I am here focusing upon legitimate critiques of the magazine content, it must be noted that facing misogynistic trolling, hate speech and threats of violence is too common a feature of daily life for female journalists (and, more generally, women who are active in the public sphere and/or publicly engage with feminism). This requires much more attention by feminist scholars, as well as, urgently, by media companies.
} 
because they're your clicks. Also they can be the beginning of a PR disaster for you. (Features editor, mid-20s, UK)

Noting how users voice their critical views about the editorial content in SNSs and comment sections, a Spanish editor stated: "there are times when you are writing things and think, 'how are they going to feel about this?'” In addition to the collective impact of resistance efforts by individual readers, also repeatedly mentioned were "prominent feminist female social media users". According to a British writer: "People do self-censor and check themselves because they're so over-analysed by feminists, popular mainstream feminists who have a massive following, the bloody Vagenda". Launched in 2012 as an online magazine by two young female journalists and later adapted into a book, the Vagenda (Cosslett and Baxter 2014) self-describes as "a big 'we call bullshit' on the mainstream women's press"11, together with a platform for women to "tell their stories [...] without it being curated by some capitalist entity" (Cosslett and Baxter 2016). For some magazine professionals: "they've got a point. A lot of the content that they criticise is rubbish and should be criticised". Most often, however, the Vagenda team was (defensively) derided and (strategically) disavowed as "hardcore", "intensely feminist women" being despotic, mean and "totally and utterly anti-women". This would then be contrasted to the publications' own (alleged) approach: "we're just there to celebrate women and be real and make them strong and empower them". Regardless of the position articulated, magazine producers declared that this feminist "labour of love" (Cosslett and Baxter 2016) has influenced publications significantly, becoming even "a voice in the head" for British producers. In the words of a content director: "if you're in a features meeting and you're talking about a rubbish idea, there is a voice in your head going, 'well, what are the Vagenda going to say about this?'”

On the whole, women's magazine journalists maintained that: "You are a lot more accountable now, for everything you write, because people can really quickly just come back at you". One illustration offered in the interviews is that of "13 Little Things That Can Make a Man Fall Hard for You". Soon after publication, this 2015 article by Glamour.com (US version) was condemned as misogynistic, sexist and regressive across SNSs, and (hence) also shortly after across news outlets (e.g. Moss 2015). Before long, Glamour.com deleted the article and issued an apology, remarking: "We hear you, tweeters"12. "So we have to listen and we do", one editor concluded. For producers, this landscape where users are speaking back and magazines are listening is what is leading to "more of an egalitarian approach to producing content". This is then advanced as the reason why "these magazines are starting at least online to approach subjects that their brand would not previously have touched", including feminism and an approach to sex described as "more risky". However, the content production process (still) fails to incorporate readers in any significant manner, maintaining a top-down practice that contradicts the repeated claims to greater dialogue and egalitarianism, and more generally that: "what we want to do is to give women a voice". For example, at a time when magazines ostensibly celebrate that "Feminism is back!"13, even professionals concede that:

There are a lot of vocal women out there who do want to talk about feminism.

\footnotetext{
${ }^{11}$ From: http://vagendamagazine.com/about/ Accessed 12/02/2016

${ }^{12}$ From: http://www.glamour.com/story/how-to-make-a-man-fall-in-love Accessed 20/02/2016

${ }^{13}$ From: http://www.femalefirst.co.uk/books/radical-feminism-finn-mackay-587163.html Accessed 01/03/2016
} 
They do want to take apart magazines and talk to us and get into conversations with us. However, sometimes we can be quite afraid of that interaction. (News editor, late 20s, UK)

Further, this "new" editorial content supposedly emerging from a greater producerreader dialogue must be interrogated with reference to new commercial strategies. In this sense, more critical voices argued that "the more extreme stuff does tend to get more air time" because "controversy is king in the era of online content, which is driven by advertising". Also highlighted was an associated click-chase imperative: "If it does nothing to make you click, it not worth writing because you don't get advertising revenue". As a result:

You've got to think what's going to make people click. They [magazines] may suddenly start writing articles about, I don't know, "'how do I use a butt plug?' Here's a product recommendation. Here's an advert for a sex toy retailer". It's a composite thing, and it's geared towards money (Freelance writer, early 30s, UK)

That is, these "new" discussions about sex (and feminism) become acceptable only once they have undergone the "ordering gaze of the market" (Jarrett 2005, 12), a gaze which is enjoying an expansion online. I was told that "we're at this pivotal moment" when the online publishing industry "is beginning to turn into this slightly less lawless thing, and there's lots of money in it". The empirical study presented here indicates that part of eradicating this perceived lawlessness is a shift in emphasis from user-generated to user-circulated content, a shift additionally driven by other factors like changing engagements with technologies and, vitally, capital accumulation. It is this "composite" paradigmatic development that I next map by way of conclusion in relation to various academic and industry literatures.

\section{From Produsers to Shareaholics: Mapping a Paradigm Shift}

$$
\text { "She is the new delivery mechanism" (Honan 2014, Wired.com) }
$$

This article is not an expression of blind nostalgia for the good old democratic days of forums in women's sites. Internet forums run by corporations have played an important role in "the naturalisation of online community as marketing maneuver", and employ a decidedly undemocratic architecture, developed to "ensure that interaction is channelled in commercially appropriate ways" (Gustafson 2002, 184, 172), and to generate "information commodities" (Andrejevic 2011b), among other things (see Campbell 2008). Nor am I advancing a dystopian argument about Big Brother 2.0. Certainly, SNSs are prototype neoliberal technologies (Hearn 2010), and a major part of "the aether of communicative capitalism's transnational historical bloc" (Kreps 2011, 697), involving a capital accumulation model "based on Internet prosumer commodification, the unpaid labour of Internet users, targeted advertising and economic surveillance" (Fuchs 2014, 255). At the same time, SNSs are used every day for activities that are enjoyable, enriching and, indeed, empowering for individuals as well as disruptive for dominant forms of power. In this respect, Jarrett $(2014,26)$ usefully observes: "as Autonomous Marxist approaches remind us, the social cooperation of users and the regimes of affect involved in digital media are always in excess 
of commodification and the capitalist labor process. This excess is potentially disruptive".

In this article, I have shown how encouraging users to "chat away to your hearts content" (Cosmopolitan UK) proved disruptive for women's online magazines and their commercial partners. In claiming this I am not engaging in the "romance of resistance" (Abu-Lughod 1990): forumers performed various types of free labour, including that of "social reproduction" (see Jarrett 2014), particularly with regard to normative gendered subjectivities, bodies and relations (see García-Favaro 2015). However, as seen in Section 4.1, these (self-identified) young women also performed what we might call a "labour of disruption", which ranged from expressions of consumer dissatisfaction with brands to the more politicized critiques of editorial lines. Against the backdrop of a reinvigorated interest in feminist ideas and activism that has been particularly notable among young women, it appears that some are becoming too-to use industry buzzwords - "discerning", "savvy" and "actively engaged" for commercial media, PRs and advertisers. In response, these industries are working hard to (re)gain centre stage in framing and setting the tone of the debate. This corporate effort is discernible in the recent proliferation of "femvertising" (see Gill and Elias 2014), and in the ways magazines have self-proclaimed as: "a game changer with regard to bringing the new feminism to young women" (Elle UK editor-in-chief) ${ }^{14}$. In such a manner, these large commercial entities operate "from within" to deradicalise imaginaries and (re)assert patriarcho-neoliberal orders of intelligibility. This importantly involves substituting political critique and collective struggle to change society with psychologies of positivity and entrepreneurial ventures to transform the self (see García-Favaro 2016 on "confidence chic"). Interestingly, perceived as most disruptive was the take up by young women of the invitation to "Drop your inhibitions and talk about all subjects sexual" (Cosmopolitan UK), demonstrating the top-down, commercially-dictated nature of the "sexualisation of culture" (see Gill 2012), and problematizing celebratory claims about a democratisation of sex and desire in contemporary mass media (McNair 2002). "Really nothing is taboo here" assures us the editor-in-chief of Cosmopolitan UK (Storr in Koman 2016). This article has demonstrated, however, that "nothing is taboo" only as long as issues/topics adhere to the tightly policed boundaries of publications and their advertisers, and once (re)articulated according to their logics of glossification and commodification.

The move away from anonymous user-led and topic-centred discussions in forums and toward brand-led and profile-centred platforms is partly an effort by corporations to control the "unruly" discourse of young women - who are in the process besides "put to work" for capital accumulation. This importantly involves the "labour of being watched": SNSs enable an unprecedented level of commercial monitoring and "one that only accelerates with the uptake of portable mobile devices" (Andrejevic 2011c, 10), which are fundamental to the current digital strategy of women's magazines. Central too is outsourcing free "24/7" targeted content circulation work, namely users sharing content across their networks of contacts. This new labouring practice entails a new audience commodification strategy. Instead of a "powerful online community" (Cosmopolitan in Superbrands 2010), magazines today are selling advertisers "hyper-connected female millennials", who "are plugged-in 24 hours a day, 7 days a week" (The Debrief 2014). Information packs additionally promise a reader who is an "active social sharer", indeed: "sharing her life online is part of her daily ritual" (The

\footnotetext{
${ }^{14}$ From: http://empowering.hearst.co.uk/be-inspired/inspiring-interviews/editors-interviewlorraine-candy-elle/ Accessed 01/03/2016
} 
Debrief 2016). Moreover, she is now "sharing like never before" (Elle 2016), publications celebrate. This ideal commodity networker, then, more than a "produser" is a "shareaholic".

The figure of the shareaholic pervades industry literatures, including neuromarketing research on "why people share online": our insatiable hunger for a "dopamine 'hit"' (RadiumOne and Steidl 2015, 4). This drug-like “'feel good' transmitter" "driving addictive and pleasure-seeking behavior" (RadiumOne and Steidl 2015, 4) is allegedly also the "key differentiating factor between male and female sharing behaviour" (Steidl 2015). To be sure, central to the industry obsession with "the psychology of sharing" (The New York Times Customer Insight Group 2011) is delineating gendered profiles, a practice that goes back to the very beginning of commercial Internet (e.g. see Shade 2004). These profiling practices (continue to) draw on highly predictable, profoundly ideological narratives, not least the postfeminist "Mars and Venus" metaphor of sexual difference (see Gill 2007), as seen in widespread claims like "Men are from LinkedIn, women are from Pinterest", which demonstrate powerful industry (and cultural) investments in "sexed brains" and (gendered) neurotechnologies (of power). Certainly, marketing experts are rejoicing that: "Developments in the area of tech-enabled neuromarketing are only going to accelerate, as brands take the initiative to unlock the value of sharing" (RadiumOne and Steidl 2015, 17). In particular, brands are recommended to "appreciate the value in gathering and activating social sharing data from the perspective of both marketing return on investment and consumer insights" (RadiumOne and Steidl 2015, 11). Strategists also enthusiastically assure brands that "social sharing" "increases receptivity to advertising" (Morgan 2015).

No doubt the interest in SNSs by women's online magazines is also due to the "imminent invasion of social commerce" (Bertram 2015). As the global financial services corporation Morgan Stanley (2015) puts it: "Social media platforms and retailers are learning how to convert 'likes' and 'followers' into 'add to my cart' and buyers". In the woman's magazine industry this interest is already materialising in new partnerships such as that established in 2015 between Cosmopolitan and Snapchat (Bernardo 2015). Indeed, young women are a central target of "social commerce". This is apparent in discussions of the "Instagram effect", namely "millennial females' anxieties about appearing too many times in the same outfit in their Internet photographs" (Felsted and Kuchler 2015) in "the age of the selfie" (Green 2015) - a good age for glossies and their partners. One case in point is the manner in which the editor-inchief of Cosmopolitan UK delineates her (ideal) reader: "I call the Cosmopolitan readers the 'selfie-made generation' [...] They really like Kim Kardashian because, again, she's self-made. She's all about the brand, she's very entrepreneurial" (Storr in Koman 2016). Like entrepreneurial Kim, the shareaholic is a selfie-made girl.

That is, the ideal "sharing subject" of SNSs is neoliberal and feminine. This gendering is also evident in appeals to the ethics of care. "Sharing is caring", reiterates commercial Internet - also as part of an attempt to eradicate the negative connotations associated to viruses. As Payne $(2013,540)$ notes: "the current discourse of media virality has paradoxically expelled its own progenitor, the virus" by rebranding viral circulation or transmission as "sharing", and with alternative notions like "spreadable media", developed by Jenkins, Ford and Green (2013). Shifting the focus away from the interface and toward the user, this notion rejects the term "viral" for purportedly obscuring the active agency of audiences and failing to capture the ways in which the "shift towards a circulation-based model for media access" involves people making "conscious" and "savvy decisions" (Jenkins in Fernandez 2014). In 
addition to the discourse of viral media, spreadable media is intended to contrast with "older models of 'stickiness"' (Jenkins in Fernandez 2014). In the latter, Jenkins et al. $(2013,5)$ explain, online publications measure the popularity of content on the basis of "which articles are viewed the most and which hold people's attention the longest". Advertisements are placed alongside the site content, and "advertising rates are based on the number of impressions a page generates or the number of clicks an ad receives" (Jenkins et al. 2013, 4). In contrast, with the spreadability (business) model: "brands enter into the spaces where people already live and interact" (Green and Jenkins 2011, 117). Building on the gift-economy logic, under the new model "grassroots intermediaries become advocates for brands" as they "circulate the content within their own communities" (Green and Jenkins 2011, 117). According to Jenkins and colleagues, this "next phase of evolution in the media ecology" (Jenkins 2009) involves a more participatory culture, and for broadcasters a crisis in the power to set the media agenda (Jenkins in Fernandez 2014). Jenkins (2009) observes that: "unruly behavior by consumers becomes a source of great anxiety within the media industry". Powerfully indicating the industry/application (and ideological) orientation of this work, Spreadable Media recommends companies to respond by outsourcing free digital labour via content sharing:

While many content creators are struggling with the growing prominence of such grassroots audience practices, an array of online communication tools have arisen to facilitate informal and instantaneous sharing. These platforms offer new capacities for people to pass along media artefacts-and, in the process, to seek models to generate revenue through the activities of their users (Jenkins et al. 2013, 2)

Ultimately, Jenkins et al. $(2013,1)$ declare: "Our message is simple and direct: if it doesn't spread, it's dead". On the basis of this logic, media industries are promoting an understanding of content sharing as the content experience itself (Potter 2016), a development which conjures Dean's $(2009,26)$ observation that under "communicative capitalism": "The exchange value of messages overtakes their use value. [...] The only thing that is relevant is circulation". Marketers imbue this circulation machinery with meaning for unpaid digital labourers by describing the "sharing economy" as that "where consumer interests and passions are shared across all online platforms" (RadiumOne and Steidl 2015, 2). Jenkins and colleagues likewise stress that media "travel through the web because they are meaningful to the people who spread them" (Jenkins 2009). Again mirroring the narratives and rationales of the market, Jenkins et al. $(2013,128)$ respond to scholarly critiques by arguing that the digital labour approach fails to acknowledge how: "audience members benefit from willing participation in such arrangements". The approaches of political economists are similarly opposed by Jenkins $(2006,248)$ as based on a "politics of victimization", whereas his own "is founded on a notion of empowerment".

These discursive moves of repudiation are familiar to critical thinkers, as are the tropes of individual responsibility, freedom, autonomy, agency, choice and empowerment. In the political field, feminists have exposed them as endeavours to delegitimise and undo radical political articulations according to-and in the service of neoliberalism (e.g. Gill 2007; McRobbie 2009; García-Favaro 2016). Concerning enarratives specifically, a Foucauldian framework would similarly highlight how the fundamental question is not ascertaining the truth or falsity of consumer empowerment, but rather interrogating the conditions or environment that demand and sustain 
it as a (desirable) discourse. Here, as Jarrett $(2003,344)$ argues, "the affective, and consequently productive, consumer" emerges as a "necessary corollary" of neoliberal economics. Under neoliberalism, Jarrett further notes $(2003,343)$, the consumer "is necessarily recognised as active and productive rather than passive and manipulated". Inspired by queer scholarship, Payne $(2014,91)$ points out how the celebratory rhetoric evident in Spreadable Media (Jenkins et al. 2013) additionally overlooks the "important elements of recognition and legibility as pillars of the subjective construction of the laboring social media user", who needs to operate within a field of norms not of her own making "at the expense of other practices and pleasures", and, moreover, in order to stay legible as subject. Besides, under the current structures: "The social network user who ceases to share ceases to be" (Payne 2014, 89). The upbeat and industry-friendly narratives of Jenkins and others additionally serve as "feel good" distractions from crucial political-economic questions about "who owns, controls and materially benefits from corporate social media", and ignore Marxisminfluenced insights about the "dialectics at work and the [complexity of the] relations of dominance we find on web 2.0" (Fuchs 2014, 61). In this respect, Jarrett $(2014,24)$ draws on Marxist feminist theorisations of social reproductive labour to highlight how: "The agency of users is not in simple opposition to the exploitative relations of capitalism but is deeply implicated in their maintenance". At the same time, as Fuchs $(2008,6)$ observes: "Web 2.0 both affirms capitalism and produces potentials that can undercut profitability".

Certainly, to the concern of women's magazines, increasing numbers of people use SNSs to share critical readings and denounce injurious representational regimes, potentially dissuading present and potential consumers. These grassroots efforts are forcing corporations to respond both to oppositional mobilisations against specific editorial decisions, and more generally, to alternative discourse. The labour of disruption of young women embodies an ongoing critical pressure for the editorial teams: "a voice in the (producers') head". Of course, publications benefit from this free digital labour in various ways, for example simply by gaining brand visibility, and by coopting subversive elements. Complicating straightforward co-optation theorisations, however, some of the young women craving less limited, limiting and toxic magazine content are also the producers of this very content, caught between ideological dilemmas, competing interests, and very real material necessities ${ }^{15}$. In fact, during my research I have at times encountered more critical positions within the industry itself than in some academic literature. This again suggests that contesting the "ideological convergence" of industry and academia ${ }^{16}$, along with the "spreadable neoliberalism" driving it, is a pressing task for critical scholars - a task that is necessarily collective and interdisciplinary.

In sum, this article has shown how multiple determinants come into play in shaping a systematic repudiation of forums and push to SNSs in women's online magazines. This includes anxieties about image and brand reputation, along with a desire to capitalise on developments in technology and use. In tracing this shift, I have raised a number of critical concerns - not least because, as the case study of Cosmopolitan UK has demonstrated, users strongly opposed the magazine's decision to close the(ir) forum. Fundamentally, I have highlighted how the new paradigm entails enlisting more unpaid consumer labour, and partly constitutes a corporate effort to (re)gain

\footnotetext{
${ }^{15}$ For example, women's magazine journalists anonymously wrote for the Vagenda.

${ }^{16}$ Epitomizing this "convergence", the research for Spreadable Media was, as explained by Jenkins (2009): "funded by the members of the Convergence Culture Consortium, including GSDM Advertising, MTV Networks, and Turner Broadcasting".
} 
control over discourse and audiences. This exercise of power has varying levels of success, and I have suggested that the "labour of disruption" offers certain potentialities for transformative subversion. But on the whole, the shifting models of reader interaction in women's online magazines pose a serious challenge to ongoing celebrations both in the industry and in some scholarly work about an increasingly democratic and user-led media landscape. Therefore, although my empirical work on changes in the woman's online magazine market speak to what Jenkins et al. (2013) call a "spreadable media paradigm" within "networked culture", it simultaneously complicates and challenges some of the central premises, approaches and assessments of this scholarship. I have instead argued for multi-causal and multidimensional explanations of the media(e)space-replete as it is with tensions and contradictions - as part of a broader sociological project inspired by a diversity of critical frameworks and concerns, including feminist ones.

\section{References}

Abu-Lughod, Lila. 1990. The Romance of Resistance: Tracing Transformations of Power Through Bedouin Women. American Ethnologist 17 (1): 41-55.

Andrejevic, Mark. 2002. The Work of Being Watched: Interactive Media and the Exploitation of Self-Disclosure. Critical Studies in Media Communication 19 (2): 230248.

Andrejevic, Mark. 2003. The Webcam Subculture ad the Digital Enclosure. In MediaSpace: Place, Scale and Culture in a Media Age, edited by Nick Couldry and Anna McCarthy, 56-76. London: Routledge.

Andrejevic, Mark. 2009. Critical media studies 2.0: An interactive upgrade. Interactions: Studies in Communication and Culture 1 (1): 35-51.

Mark, Andrejevic. 2011a. The Work That Affective Economics Does. Cultural Studies, 25 (4-5): 604-620.

Andrejevic, Mark. 2011b. Social Network Exploitation. In A Networked Self: Identity, Community, and Culture on Social Network Sites, edited by Zizi Papacharissi, 82111. New York: Routledge.

Andrejevic, Mark. 2011c. Estrangement 2.0. World Picture 6. http://www.worldpicturejournal.com/WP 6/Andrejevic.html

Balka, Ellen. 1999. Where Have all the Feminist Technology Critics Gone? Loka Alert 6:6. Accessed March 20, 2016. http://www.loka.org/alerts/loka.6.6.txt

Ballaster, Ros, Margaret Beetham, Elizabeth Frazer and Sandra Hebron. 1991. Women's Worlds. Ideology, Femininity and the Woman's Magazine. London: Macmillan.

Baquia. 2001. Las mujeres no son tontas, la que viene a nosotros sabe lo que va a encontrar, Baquia. Accessed January 5, 2016. http://www.baquia.com/posts/lasmujeres-no-son-tontas-la-que-viene-a-nosotros-sabe-lo-que-va-a-encontrar-2

Baym, Nancy K. 1995. The emergence of community in computer-mediated communication. In CyberSociety: Computer-mediated communication and community, edited by Steven G. Jones, 138-163. Thousand Oaks: Sage Publications.

Baxter, Holly and Rhiannon Lucy Cosslett. 2014. The Vagenda: A Zero Tolerance Guide to the Media. London: Square Peg.

Baxter, Holly and Rhiannon Lucy Cosslett. 2016. Presentation at "The Vagenda two years on: what has changed?" London, May 4. 
Bernardo, Olivia. 2015. Cosmopolitan Debuts on Snapchat Discover, The Association of Magazine Media. Accessed February 26, 2016.

http://www.magazine.org/industry-news/press-releases/member-pressreleases/cosmopolitan-debuts-snapchat-discover

Bertram, Alec. 2015. The imminent invasion of social commerce, The Guardian. Accessed February 26, 2016. http://www.theguardian.com/small-businessnetwork/2015/jul/30/invasion-social-commerce-amazon-facebook-twitter

Brail, Stephanie. 1996. The Price of Admission: Harassment and Free Speech in the Wild, Wild West. In Wired Women: Gender and New Realities in Cyberspace, edited by Lynn Cherny and Elizabeth Reba Weise, 141-57. Seattle: Seal.

Brown, Janelle. 2000. What happened to the women's Web? Salon.com, August 25. Accessed May 1, 2016. http://www.salon.com/2000/08/25/womens_web/

Bruns, Axel. 2007. Produsage: Towards a Broader Framework for User-Led Content Creation. Proceedings of the 6th ACM SIGCHI conference on Creativity \& Cognition, 99-106. Accessed April 16, 2016. http://eprints.qut.edu.au/6623/1/6623.pdf

Campbell, John Edward. 2008. Virtually Home: The Commodification Of Community In Cyberspace. Unpublished PhD thesis, University of Pennsylvania.

Campbell, John Edward. 2011. It Takes an iVillage: Gender, Labour, and Community in the Age of Television-Internet Convergence. International Journal of Communication 5: 492-510.

CNET. 2002. Women's sites seek to separate from crowd. Accessed February 7, 2016. http://www.cnet.com/uk/news/womens-sites-seek-to-separate-from-crowd/

Consalvo, Mia. 2002. Selling the Internet to women: The early years. In Women and everyday uses of the Internet: Agency and identity, edited by Mia Consalvo and Susanna Paasonen, 111-138. New York: Peter Lang.

Consalvo, Mia and Susanna Paasonen. 2002. On the Internet, Women Matter. In Women and everyday uses of the Internet: Agency and identity, edited by Mia Consalvo and Susanna Paasonen, 1-18. New York: Peter Lang.

Cosmopolitan. 2016. Media pack. Hearst Magazines UK. Accessed April 7, 2016. http://hearstcouk.wp.cdnds.net/tmp/wpro1455721699558662/2016/02/15123209/C osmoMediaPack_2016.pdf

Davies Jones, Kate. 2015. Bodybuilding Forums Are One of the Last Relics of Web 1.0, Vice. Accessed February 7, 2016.

https://www.vice.com/en_uk/read/bodybuilding-forums-are-one-of-the-last-relicsof-web-10-456

Dean, Jodi. 2009. Democracy and Other Neoliberal Fantasies: Communicative Capitalism and Left Politics. Durham, NC: Duke University Press.

Deuze, Mark. 2008. Corporate appropriation of participatory culture. In Participation and media production: Critical reflections on content creation, edited by Nico Carpentier and Benjamin De Cleen, 27-40. Newcastle upon Tyne, UK: Cambridge Scholars Publishers.

Devon, Natasha. 2015. Stuff, The Real Beauty Debate Blog. Accessed February 10, 2016. http://realbeautydebate.blogspot.co.uk/2015/01/stuff.html

Driscoll, Catherine and Melissa Gregg. 2011. Convergence Culture and The Legacy of Feminist Cultural Studies. Cultural Studies 25 (4-5): 566-584.

Duffy, Brooke Erin. 2011. Magazines without the magazine: Remaking boundaries in an era of media convergence. Unpublished PhD thesis, University of Pennsylvania. 
Duffy, Brooke Erin. 2013. Remake, Remodel: Women's Magazines in the Digital Age. Urbana-Champaign, IL: University of Illinois Press.

Eble, Michelle and Robin Breault. 2002. The primetime agora: Knowledge, power, and "mainstream" resource venues for women online. Computers and Composition 19 (3): 315-329.

Elle. 2016. Media information. Hearst Magazines UK. Accessed April 7, 2016. http://hearstcouk.wp.cdnds.net/tmp/wpro1455725378862303/2016/02/15122730/E LLE16-MEDIAINFO.pdf

Felsted, Andrea and Hannah Kuchler. 2015. Instagram: Retail's holy grail, Financial Times. Accessed February 26, 2016. http://www.ft.com/cms/s/0/bef817ae-31f111e5-91ac-a5e17d9b4cff.html\#axzz41H6Y0hPC

Ferguson, Marjorie. 1983. Forever Feminine: Women's Magazines and the Cult of Femininity. London: Heinemann Educational Books Ltd.

Fernandez, Julia. 2014. Understanding the Participatory Culture of the Web: An Interview with Henry Jenkins. Accessed April 10, 2016.

https://blogs.loc.gov/digitalpreservation/2014/07/understanding-the-participatoryculture-of-the-web-an-interview-with-henry-jenkins/

Frazer, Elizabeth. 1987. Teenage Girls Reading Jackie. Media, Culture \& Society 9 (4): 407-425.

Fuchs, Christian. 2008. Review essay of "Wikinomics: How Mass Collaboration Changes Everything", by Don Tapscott and Anthony D. Williams. International Journal of Communication 2: 1-11.

Fuchs, Christian. 2009. Information and Communication Technologies and Society: A Contribution to the Critique of the Political Economy of the Internet. European Journal of Communication 24 (1): 69-87.

Fuchs, Christian. 2014. Social Media: A Critical Introduction. London: Sage.

García-Favaro, Laura. 2015. "Porn Trouble": On the Sexual Regime and Travels of Postfeminist Biologism. Australian Feminist Studies 30 (86): 366-376.

García-Favaro, Laura. 2016. "Just be confident girls!”: Confidence Chic as Neoliberal Governmentality. In Aesthetic Labour: Rethinking beauty politics in neoliberalism, edited by Ana Sofia Elias, Rosalind Gill and Christina Scharff. London: Palgrave Macmillan.

García-Favaro, Forthcoming. Transnational Technologies of Gender and Mediated intimacy. PhD thesis, City University London.

Genusa, Angela. 2001. Women's Websites Insult My Intelligence, CIO Magazine. Accessed February 5, 2016. http://www.cio.com/article/2441610/Internet/womens-websites-insult-my-intelligence.html

Gill, Rosalind. 2007. Gender and the Media. Cambridge: Polity Press.

Gill, Rosalind. 2012. The Sexualisation of Culture? Social and Personality Psychology Compass 6 (7): 483-498.

Gill, Rosalind and Ana Sofia Elias. 2014. "Awaken Your Incredible”: Love Your Body Discourses and Postfeminist Contradictions. International Journal of Media \& Cultural Politics 10 (2): 179-88.

Gough-Yates, Anna. 2003. Understanding women's magazines: Publishing, markets and readerships. London: Routledge.

Green, Chris. 2015. Instagram and Facebook have "totally changed" the way people buy clothes in the age of the selfie, The Independent. Accessed February 28, 2016. http://www.independent.co.uk/life-style/fashion/news/instagram-and- 
facebook-have-totally-changed-the-way-people-buy-clothes-in-the-age-of-theselfie-10419806.html

Green, Joshua and Henry Jenkins. 2011. Spreadable Media: How Audiences Create Value and Meaning in a Networked Economy. In The Handbook of Media Audiences, edited by Virginia Nightingale, 109-127. Malden, MA: Wiley-Blackwell.

Gustafson, Karen. E. 2002. Join Now, Membership Is Free: Women's Web Sites and the Coding of Community. In Women and Everyday Uses of the Internet: Agency and Identity, edited by Mia Consalvo and Susanna Paasonen, 168-188. New York: Peter Lang.

Hardt, Michael and Antonio Negri. 2004. Multitude: War and Democracy in the Age of Empire. New York: Penguin Press.

Hearn, Alison. 2010. Structuring Feeling: Web 2.0, Online Ranking and Rating, and the Digital "Reputation" Economy. Ephemera 10 (3/4): 421-438.

Hermes, Joke. 1995. Reading Women's Magazines. An Analysis of Everyday Media Use. Cambridge: Polity.

Herring, Susan, Kirk Job-Sluder, Rebecca Scheckler and Sasha Barab. 2002. Searching for Safety Online: Managing "Trolling" in a Feminist Forum. The Information Society 18 (5): 371-384.

Honan, Mat. 2014. Inside the Buzz-Fueled Media Startups Battling for Your Attention, Wired. Accessed March 3, 2016. http://www.wired.com/2014/12/new-media-2/

InPublishing. 2011. Cosmopolitan.co.uk unveils redesign. Accessed February 10, 2016.

http://www.inpublishing.co.uk/news/articles/cosmopolitancouk_unveils_redesign.a spx

InPublishing. 2014. Cosmopolitan.co.uk relaunches with "mobile-first" design. Accessed February 10, 2016.

http://www.whatsnewinpublishing.co.uk/content/cosmopolitancouk-relaunches\%E2\%80\%98mobile-first\%E2\%80\%99-design

Jarrett, Kylie. 2003. Labour of Love: An Archaeology of Affect as Power in ECommerce. Journal of Sociology 34 (4): 335-351.

Jarrett, Kylie. 2005. Ordering Disorder: ninemsn, Hypertext and Databases. M/C Journal 7 (6). Accessed March 3, 2015. http://journal.mediaculture.org.au/0501/07-jarrett.php

Jarrett, Kylie. 2014. The Relevance of "Women's Work": Social reproduction and immaterial labour in digital media. Television and New Media 15 (1): 14-29.

Jenkins, Henry. 2006. Convergence Culture: Where Old and New Media Collide. New York: New York University Press.

Jenkins, Henry. 2009. If It Doesn't Spread, It's Dead (Part One): Media Viruses and Memes. Confessions of an Aca-Fan: The Official Weblog of Henry Jenkins. Accessed April 15, 2016.

http://henryjenkins.org/2009/02/if_it_doesnt_spread_its_dead_p.html

Jenkins, Henry, Sam Ford and Joshua Green. 2013. Spreadable media: Creating value and meaning in a networked culture. New York: New York University Press.

Jhally, Sut and Bill Livant. 1986. Watching as working: The valorization of audience consciousness. Journal of Communication 36 (3): 124-143.

Koman, Tess. 2016. What It's Like to Be the Editor of Cosmo U.K, Cosmopolitan US. Accessed February 1, 2016.

http://www.cosmopolitan.com/career/news/a51231/cosmo-uk-farrah-storr-eicinterview 
Kramarae, Cheris and $\mathrm{H}$. Jeanie Taylor. 1993. Women and Men on Electronic Networks: A Conversation or a Monologue? In Women, Information Technology, \& Scholarship, edited by $\mathrm{H}$. Jeanie Taylor, Cheris Kramarae and Maureen Ebben, 52-61. University of Illinois, Urbana-Champaign.

Kreps, David. 2011. Social Networking and Transnational Capitalism. tripleC: Communication, Capitalism \& Critique 9 (2): 689-701. Accessed March 3, 2016. http://www.triple-c.at/index.php/tripleC/article/view/267

Lévy, Pierre. 1997. Collective Intelligence: Mankind's Emerging World in Cyberspace. Cambridge: Perseus Books.

Litosseliti, Lia. 2006. Gender and Language: Theory and Practice. London: Hodder Arnold.

Macdonald, Myra. 1995. Representing Women: Myths of Femininity in the Popular Media. New York: St. Martin's Press.

McCracken, Ellen. 1993. Decoding Women's Magazines: From Mademoiselle to Ms. Houndmills and Hampshire: Macmillan.

McNair, Brian. 2002. Striptease Culture: Sex, Media and the Democratization of Desire. London: Routledge.

McRobbie, Angela. 1996. More! New Sexualities in Girls and Women's Magazines. In Cultural Studies and Communications, edited by James Curran, David Morley and Valerie Walkerdine, 172-194. London: Arnold.

McRobbie, A. 2009. The Aftermath of Feminism: Gender, Culture and Social Change. London: Sage.

Morgan Stanley. 2015. The Rise of the Social (Commerce) Network. Accessed February 26, 2016. http://www.morganstanley.com/ideas/social-commerce-network

Moss, Rachel. 2015. Glamour's Tips On "How To Make A Man Fall For You" Make Our Blood Boil, The Huffington Post UK. Accessed May 1, 2016. http://www.huffingtonpost.co.uk/2015/07/27/glamour-how-to-make-a-man-fall-inlove-sexist n 7879816.html

Murphy, Rewa Therese. 2013. (De)Constructing "body love" discourses in young women's magazines. Unpublished PhD thesis, University of Wellington.

Ouellette, Laurie and Julie Wilson. 2011. Women's work: Affective labour and convergence culture. Cultural Studies 25 (4-5): 548-565.

Paasonen, Susanna. 2002. The Woman Question: Addressing women as internet users. In Domain Errors: Cyberfeminist Practice, edited by Maria Fernandez, Faith Wilding and Michelle M. Wright, 89-108. New York: Andromeda.

Payne, Robert. 2013. Virality 2.0: Networked Promiscuity and the Sharing Subject. Cultural Studies 27 (4): 540-60.

Payne, Robert. 2014. Frictionless Sharing and Digital Promiscuity. Communication and Critical/Cultural Studies 11 (2): 85-102.

Pearce, Celia. 1997. The Interactive Book: A Guide to the Interactive Revolution. Indianapolis: Macmillan.

Pfanner, Eric. 2010. AuFeminin Looks to Expand Its Reach, The New York Times. Accessed February 7, 2016. http://www.nytimes.com/2010/11/08/technology/08ihtaufem.html? $r=0$

Plant, Sadie. 1996. On the matrix: Cyberfeminist simulations. In Cultures of Internet: Virtual Spaces, Real Histories, Living Bodies, edited by Rob Shields, 170-183. Thousand Oaks, CA: Sage. 
Potter, Matt. 2015. Is social media really shrinking our attention spans? John Brown. Accessed May 5, 2016. http://www.johnbrownmedia.com/thinking/socialmedia/social-media/

Price, Anita. 1998. A Wide World for Women, wwwiz Magazine. Accessed February 7, 2016. http://wwwiz.com/issue37/html/article6.html

RadiumOne and Steidl, Peter. 2015. Drugs Data \& Tech: Has marketing utopia arrived? Accessed March 2, 2016.

http://info.radiumone.com/rs/207-XL/-

813/images/RadiumOne_Research_Drugs_Data_Tech.pdf

Royal, Cindy. 2005. Gendered Spaces and Digital Discourse: Framing Women's Relationship with the Internet. Unpublished PhD thesis, The University of Texas at Austin.

Sadowska, Noemi. 2002. Women's Internet Sites: A Search for Design Strategies to Engage the Female Viewer. In Women and Everyday Uses of the Internet: Agency and Identity, edited by Mia Consalvo and Susanna Paasonen, 90-107. New York: Peter Lang.

Sarvary, Miklos. 2012. Social publishers: a new paradigm for online media, INSEAD Knowledge. Accessed May 1, 2016. http://knowledge.insead.edu/blog/inseadblog/social-publishers-a-new-paradigm-for-online-media-2778

Sauty de Chalon, Marie-Laure. 2011. Presenting Womenology. Accessed April 20, 2016. http://www.womenology.com/marketing-watch/presenting-womenologyinterview-marie-laure-sauty-de-chalon/

Scholz, Trebor, ed. 2013. Digital Labour: The Internet as Playground and Factory. New York: Routledge.

Seiter, Ellen. 2003. Television and the Internet. In Gender Race and Class in Media, edited by Gail Dines and Jean M. Humez, 688-695. Thousand Oaks, CA: Sage. Sage: Thousand Oaks, CA.

Shade, Leslie Regan. 2004. Bending gender into the net: Feminizing content, corporate interests, and research strategy. In Society online: The internet in context, edited by Philip N. Howard and Steve Jones, 57-71. Thousand Oaks, CA: Sage.

Smythe, Dallas. 1977. Communications: Blindspot of western Marxism. Canadian Journal of Political and Social Theory 1 (3): 1-27.

Steidl, Peter. 2015. Five ways to tap into women's online sharing habits - and how they differ from men's, Marketing. Accessed May 1, 2016. https://www.marketingmag.com.au/hubs-c/five-ways-tap-womens-online-sharinghabits-differ-mens/

Superbrands. 2010. Cosmopolitan. Accessed January 10, 2016. http://sbbsdev.com/index.php?option=com_docman\&task=doc_download\&gid $=50$ 15\&Itemid $=74$

Talbot, Mary M. 1995. A synthetic Sisterhood: false friends in a teenage magazine. In Gender Articulated: Language and the Socially Constructed Self, edited by Kira Hall and Mary Bucholtz, 143-65. London: Routledge.

Tapscott, Don and Anthony D. Williams. 2006. Wikinomics: how mass collaboration changes everything. London: Penguin.

Terranova, Tiziana. 2000. Free Labour: Producing Culture for the Digital Economy. Social Text 63, 18 (2): 33-58.

The Debrief. 2014. Media pack. Bauer Media. Accessed April 7, 2016. https://www.bauermedia.co.uk/uploads/Debrief\%20.pdf 
The Debrief. 2016. Media pack. Bauer Media. Accessed April 7, 2016. www.bauermedia.co.uk/uploads/The_Debrief_Media_Pack_2016_TEST.pdf

The New York Times Customer Insight Group. 2011. The Psychology of Sharing: Why do people share online? Accessed May 1, 2016. http://nytmarketing.whsites.net/mediakit/pos/

Van Zoonen, Liesbet. 2001. Feminist Internet Studies. Feminist Media Studies 1 (1): 67-72.

Welton, Caysey. 2015. Behind Cosmo's Mobile-First Approach. A Q\&A with Cosmopolitan.com's editor, Amy Odell, Folio. Accessed May 1, 2016. http://www.foliomag.com/2015/behind-cosmos-mobile-first-approach/

Winship, Janice. 1987. Inside Women's Magazines. London: Pandora.

Wolf, Naomi. 1991. The Beauty Myth: How Images of Beauty Are Used Against Women. New York: Vintage.

Worthington, Nancy. 2005. Women's Work on the World Wide Web: How a New Medium Represents an Old Problem. Popular Communication: The International Journal of Media and Culture 3 (1): 43-60.

\section{About the Author}

Laura García-Favaro is a PhD candidate in the Department of Sociology at City University London. 